\title{
Melostelis gen. nov., espécies novas e notas complementares sobre Anthidiini (Hymenoptera, Apidae) ${ }^{1}$
}

\author{
Danúncia Urban ${ }^{2}$
}

${ }^{1}$ Contribuição no 1829 do Departamento de Zoologia, Universidade Federal do Paraná.
${ }^{2}$ Laboratório de Biologia Comparada de Hymenoptera, Departamento de Zoologia, Universidade Federal do Paraná, Caixa Postal 19020,
81531-980 Curitiba-PR, Brasil. Bolsista do CNPq. urban@ufpr.br

\begin{abstract}
Melostelis gen. nov., new species and complementary notes on Anthidiini (Hymenoptera, Apidae). Melostelis gen. nov. is proposed to a new cleptoparasitic Anthidiini. Two new species, Melostelis amazonensis sp. nov. from Manaus, Amazonas and Larocarathidium chacoense sp. nov. from Porto Murtinho, Mato Grosso do Sul, are described and illustrated. The males from Epanthidium bolivianum Urban, 1995 and Epanthidium araranguense Urban, 2006, are described. The occurrences from Ketianthidum zanolae Urban, 2000 and Epanthidium bolivianum, are registred by the first time in the Brazilian Chacoan subregion.
\end{abstract}

KEYWORDS. Megachilinae; new genus; new species; neotropical; taxonomy.

RESUMO. Melostelis gen. nov., espécies novas e notas complementares sobre Anthidiini (Hymenoptera, Apidae). Melostelis gen. nov. é proposto para um novo Anthidiini cleptoparasita. São descritas e ilustradas duas espécies novas: Melostelis amazonensis sp. nov. de Manaus, Amazonas e Larocanthidium chacoense sp. nov. de Porto Murtinho, Mato Grosso do Sul. São dados a conhecer os machos de Epanthidium bolivianum Urban, 1995 e Epanthidium araranguense Urban, 2006 e, registrados pela primeira vez no Brasil, na sub-região do chaco, Ketianthidium zanolae Urban, 2000 e Epanthidium bolivianum.

PALAVRAS-CHAVE. Espécies novas; gênero novo; Megachilinae; neotropical; taxonomia.

Três gêneros de Anthidiini cleptoparasitas ocorrem no Brasil parasitando ninhos de outros Anthidiini e de Euglossa (Apidae) (Silveira et al. 2002). As fêmeas de Austrostelis Michener \& Griswold, 1988 são reconhecidas pelo porte pequeno e mandíbulas não modificadas, as de Hoplostelis Dominique, 1898 e Rhynostelis Moure \& Urban, 1994, possuem modificações nas mandíbulas e porte mediano. A fêmea de Rhynostelis tem tubérculo basal no clípeo, áreas gibosas no mesossoma e carena omaular longa, laminada na metade dorsal. Melostelis gen. nov. é descrito com base em uma fêmea de porte mediano, sem modificações nas mandíbulas e sem tubérculo basal no clípeo, a carena omaular até o meio dos mesepisternos. É proposta uma espécie nova para Larocanthidium Urban, 1997, com dez espécies conhecidas que ocorrem no Brasil, do Maranhão ao Paraná, incluindo a região centro-oeste. A terminologia é a comumente utilizada nas descrições das abelhas e as medidas são dadas em milímetros. A asa anterior foi medida a partir do esclerito costal e as distâncias interorbitais foram obtidas entre as extremidades da margem reta das órbitas. O material-tipo das espécies propostas está depositado na Coleção Entomológica Pe. J. S. Moure, Curitiba (DZUP).

\section{Melostelis gen. nov.}

Espécie-tipo: Melostelis amazonensis sp. nov.

Diagnose. Mandíbulas da fềmea quadridentadas, com pontos esparsos e área basal polida; clípeo pouco protuberante, com dois tubérculos marginais arredondados separados por uma pequena área côncava mediana; carenas interalveolares longas, área basal do propódeo com alvéolos longos e polidos.

Fêmea. Tegumento denso-pontuado na cabeça e mesossoma, nos tergos os pontos menos densos. Mandíbulas quadridentadas com o dente inferior longo e os demais muito curtos, com pontos e rúgulas esparsos, a área basal fracamente deprimida e desprovida de pontos, carena ínferolateral larga e baixa, até o meio da mandíbula e a carena externa superior pouco conspícua, fina e reta, não unida à ínfero-lateral. Labro com um tubérculo médio-basal arredondado e baixo; clípeo e área supraclipeal um pouco protuberantes, ponta do clípeo lisa nos lados, com dois tubérculos marginais arredondados separados por uma área côncava mediana menor que a distância interalveolar; área supraclipeal sem pontos no disco; carenas interalveolares laminadas e em arco rebaixado, um pouco inclinadas para os alvéolos, com as extremidades pouco elevadas, paralelas na ponta dorsal e um pouco convergentes ventralmente; carenas paroculares quase até o topo dos olhos; carena pré-occipital ausente. Antenas com o escapo tão longo como o dobro da distância interalveolar, o flagelômero basal curto, tão longo como 2/3 da sua largura e o segundo tão longo como largo. Lobo pronotal com lâmina sinuosa, mais curta junto ao mesoscuto; o escutelo alongado para trás e ultrapassando o metanoto, com depressão basal polida estreita e fracamente interrompida no meio, depressão médio-longitudinal pontuada, o bordo posterior arqueado e com chanfro mediano; 
axilas com o bordo posterior arredondado; metanoto microreticulado, sem pontos; propódeo com alvéolos longos e polidos na área basal, a área pós-espiracular quase triangular, estreitando em direção ao disco do propódeo e com pontuação grossa micro-reticulada; asas com o pterostigma mais longo na margem costal; mesepisternos convexos, com carena omaular na metade dorsal e sem área discal elevada; tíbias anteriores e medianas com projeção apical espiniforme curta, medindo cerca da metade do diâmetro do ocelo mediano; basitarsos posteriores sem carena ao longo do comprimento; arólios presentes. Tergo basal sem carena, com uma faixa estreita polida e sem pontos, entre a face anterior e a dorsal; tergo distal curto e largo, sem elevação no disco, deprimido subapicalmente e com o bordo um pouco voltado para cima, a área deprimida com uma fóvea mediana arredondada; esternos sem modificações.

Comentários. Pelas chaves de Silveira et al. (2002) e de Michener (2000) a fêmea de Melostelis gen. nov. sai com Austrostelis pelo aspecto das mandíbulas, sem modificações e sem protuberância basal. Entretanto Austrostelis se distingue de Melostelis pelos seguintes caracteres: porte pequeno; área basal das mandíbulas com pontos grandes e densos; margem do clípeo com pequenas tuberosidades; carenas interalveolares com a ponta dorsal arqueada para o meio; tíbias anteriores e medianas com projeção espiniforme apical tão longa como o diâmetro do ocelo mediano ou pouco mais curta e, pelas áreas pós-espiraculares do propódeo elipsóides e com alvéolos brilhantes. Tendo recebido do Prof. Dr. Gabriel A. R. Melo, fotos de um Anthidiini coletado em Guanacaste, Costa Rica, do Dr. Terry L. Griswold, Logan, USA, foi possível identificá-lo como Melostelis gen. nov. Aparentemente é uma segunda espécie do gênero.

Etimologia. Nome em homenagem ao Prof. Dr. Gabriel Augusto Rodrigues de Melo do Departamento de Zoologia, UFPR.

\section{Melostelis amazonensis sp. nov.}

(Figs. 1-3)

Diagnose. Fêmea com o tegumento em grande parte amarelo, com máculas pretas na cabeça, o mesoscuto preto com duas máculas amarelas largas em "U” invertido e os tergos pretos com faixa discal amarela.

Holótipo fêmea. Comprimento aproximado 12,51; comprimento da asa 9,01; largura da cabeça 3,8; comprimento do olho 2,69; distância interorbital superior 2,35 e a inferior 1,91. Tegumento predominante amarelo. Cabeça com três grandes máculas pretas, duas largas e longas, dos alvéolos antenais quase até os ocelos laterais, mais estreitas dorsalmente e, mácula trilobada no vértice, com os lobos laterais menores, arredondados posteriormente e com o contorno anterior reto, o lobo mediano com o contorno posterior reto e incluindo a área ocelar porém deixando duas pequenas nódoas amarelas entre os ocelos laterais; nódoa preta médio-dorsal no occipício; as mandíbulas com a carena superior interna e os dentes pretos, a área preta mais larga junto ao dente inferior. Face ventral do escapo amarela, o restante do escapo, o pedicelo e o flagelômero basal castanhos, demais flagelômeros pretos. Mesoscuto com duas máculas muito largas amarelas em "U" invertido reduzindo as áreas pretas a três estrias; escutelo e axilas amarelos, o escutelo com a base preta muito larga no meio e estreitando para os lados, as axilas com pequena área preta basal; metanoto castanho claro com áreas laterais amarelas; propódeo amarelo com as áreas pós-espiraculares pretas e quase triangulares, estreitamente unidas a uma mancha posterior preta trilobada. Tégulas âmbar com estria amarelada submarginal no contorno anterior e junto ao mesoscuto. Asas tingidas de castanho, com uma tonalidade mais escura na ponta, as veias pretas. Pernas amarelas. Mesepisternos amarelos com pequena área médio-basal preta. Tergo basal amarelo com faixa dorsal preta, muito estreita no meio e ausente nos flancos, a faixa marginal enegrecida e estreita; segundo ao quinto tergo enegrecidos na base e no ápice, a faixa amarela mais larga no segundo; a margem anterior da faixa amarela com pequeno chanfro mediano e recorte sinuado nos lados; margem translúcida acastanhada e muito estreita nos flancos e na parte ventral dos tergos; tergo distal amarelo com área basal enegrecida e nódoa preta na depressão subapical, o bordo preto. Esternos com uma tonalidade muito pálida de castanho e faixa discal amarela, a faixa muito estreita no primeiro e do terceiro ao quinto, notavelmente larga no segundo.

Holótipo fêmea. Brasil, Amazonas. "Brasil, Amazonas, Manaus,/Margem do Rio Negro; Praia do/Tupé; 22.10.2006; AJC Aguiar", "DZUP/029442” (DZUP).

Comentários. Pelo porte e colorido do tegumento lembra a fêmea de Rhynostelis multiplicata (Smith, 1879) que difere pelo clípeo achatado e com uma projeção basal em forma de tubérculo; mandíbulas modificadas, com projeção angulosa larga e alta junto à articulação superior, depressão discal profunda entre a projeção e a carena externa inferior e outra depressão triangular junto à base; pelas áreas gibosas no mesoscuto, escutelo, axilas e mesepisternos; carena omaular longa, laminada na metade dorsal; tíbias anteriores e medianas com o espinho apical grande, tão longo como o diâmetro do ocelo mediano.

Macho desconhecido.

Etimologia. Nome relativo ao local de coleta.

\section{Larocanthidium chacoense sp. nov.}

(Figs. 8-12)

Diagnose. Macho com as mandíbulas, clípeo e as paroculares inferiores amarelos; mesoscuto com máculas laterais em "J" invertido, amarelas na base e ferrugíneas nos lados; sexto tergo com pequena angulosidade mediana na projeção subapical laminada. Fêmea com escutelo e axilas ferrugíneos; terceiro ao quinto tergo com faixa amarela, um pouco interrompida no terceiro; escopa branca.

Holótipo macho. Comprimento aproximado 6,70; comprimento da asa 4,88; largura da cabeça 2,32; comprimento do 


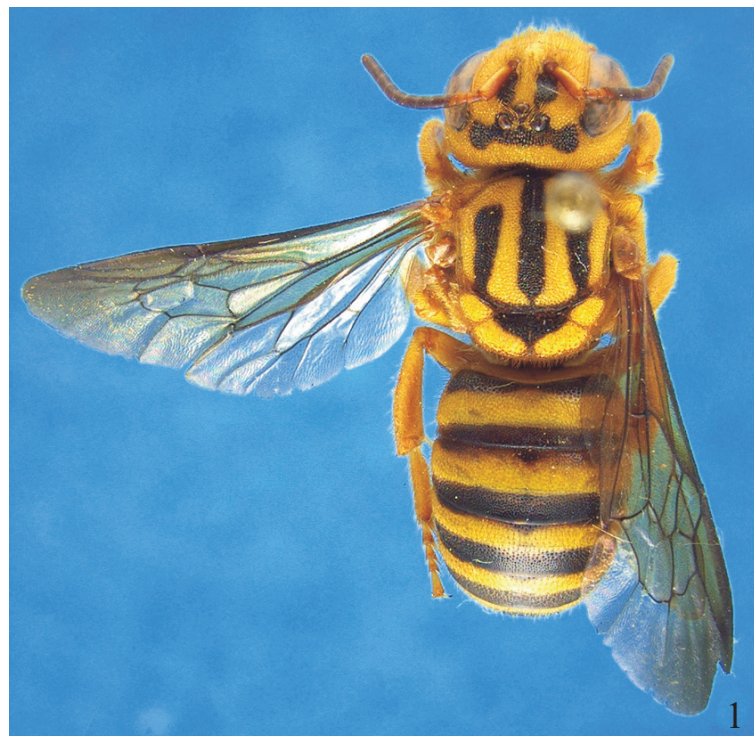

2
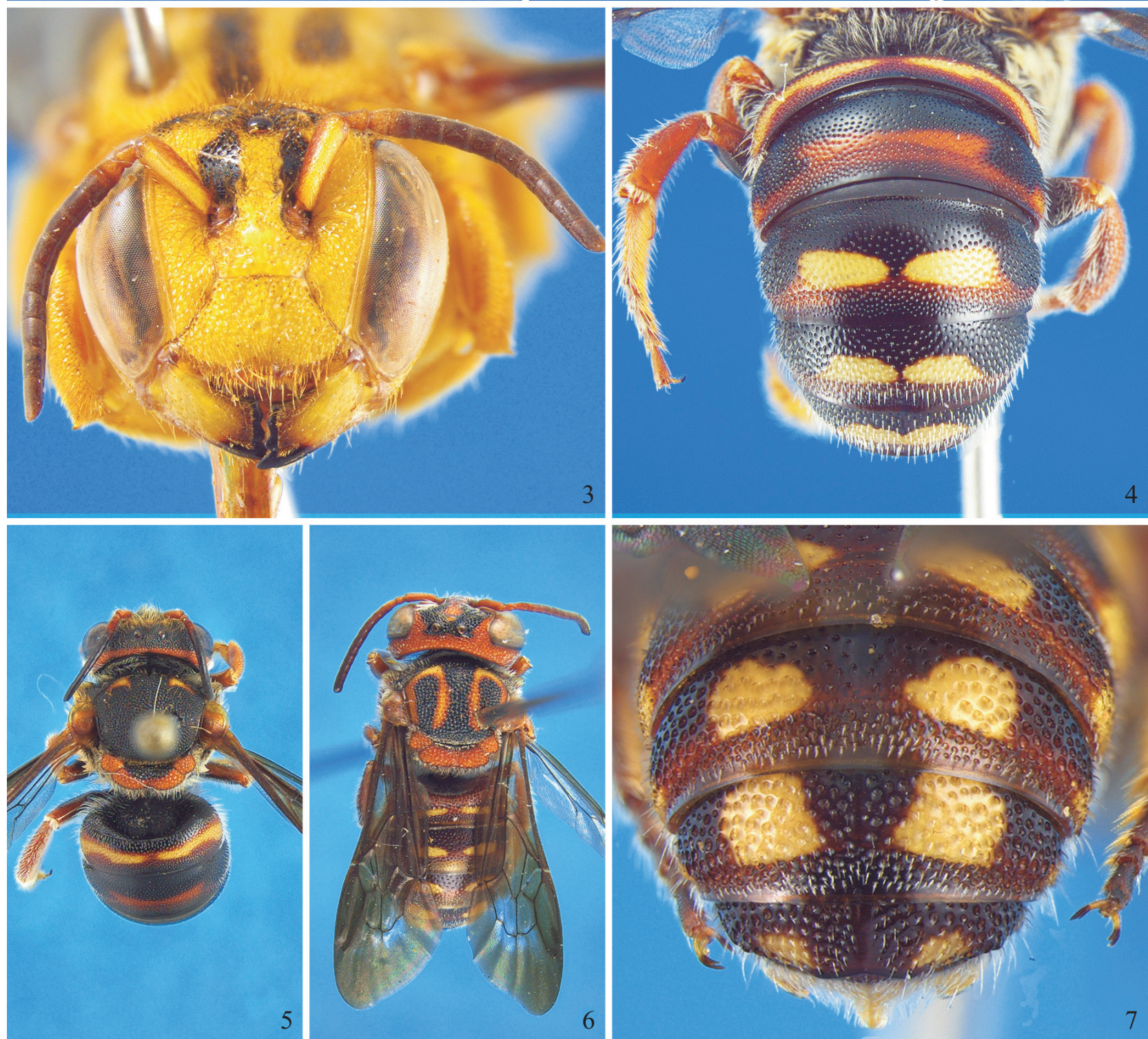

Figuras 1-7. Espécies de Anthidiini. (1-3) Melostelis amazonensis sp. nov. Holótipo fêmea: 1, vista dorsal; 2, perfil; 3, cabeça. (4-5) Epanthidium araranguense, macho: 4, tergos; 5, vista dorsal. (6-7) Epanthidium bolivianum, macho: 6, vista dorsal; 7, tergos distais. 
olho 1,58; distância interorbital superior 1,40 e a inferior 1,08. Tegumento predominante preto. Cabeça em grande parte amarela passando a amarelo-ferrugínea em parte das paroculares superiores, na altura dos ocelos, no vértice e na metade dorsal das genas; face com uma grande mácula preta frontal, mais larga dorsalmente, incluindo a área ocelar e parte das paroculares superiores e contornando a nódoa interalveolar amarela, a mácula preta até as suturas subantenais e a epistomal. As mandíbulas amarelas com áreas acastanhadas e os dentes pretos; clípeo, paroculares inferiores e mácula interalveolar amarelos, a mácula interalveolar quase quadrangular, com duas angulosidades curtas ventrais; as carenas interalveolares translúcidas e fracamente acastanhadas; genas enegrecidas na metade ventral. Antenas com o escapo, a face ventral do pedicelo e do flagelo ferrugíneos; dorsalmente ferrugíneas até o quarto flagelômero, no restante castanho-escuras. Lobos pronotais amarelos ventralmente, com uma pequena área ferrugínea discal e pretos dorsalmente; mesoscuto com duas máculas laterais em "J" invertido, amarelas na base e ferrugíneas no restante; escutelo e axilas ferrugíneos, o escutelo com uma estreita área preta junto ao mesoscuto. Tégulas âmbar; as asas tingidas de enegrecido e as veias pretas; pernas ferrugíneas, menos as coxas e os trocanteres enegrecidos, com uma estria amarelo-ferrugínea na face externa dos fêmures e tíbias anteriores e nas tíbias medianas; os basitarsos anteriores e os posteriores com a face externa amarelo-pálida. Tergos pretos na base, com faixa marginal castanho-ferrugínea do primeiro ao terceiro, nos dois seguintes a faixa enegrecida, no sexto tergo acastanhada, fina e translúcida; o primeiro tergo com faixas laterais amarelas largas, mais afastadas da margem e um pouco mais estreitas para o meio do tergo, separadas por pequena área enegrecida; o segundo com nódoas amarelas látero-ventrais ovaladas; do terceiro ao sexto com faixa amarela discal larga, a faixa com um pequeno chanfro anterior no terceiro, quarto e sexto tergos, no terceiro levemente acastanhada no meio; a faixa do quinto tergo larga dorsalmente e mais estreita nos lados; sétimo tergo amarelo na metade distal. Esternos castanho-amarelados com área basal castanhoenegrecida.

Pilosidade branca. Coxas anteriores com espinho apical tão longo como o diâmetro do ocelo mediano; segundo ao sexto tergo com depressões marginais nos flancos; tégulas polidas com pontuação rasa e densa; sexto tergo com a projeção subapical laminada, perpendicular ao restante do tergo, estreita nos lados e com uma pequena angulosidade mediana; sétimo tergo com os lobos laterais estreitos e achatados, separados por recorte largo e fracamente arqueado, os lobos mais estreitos que a metade do recorte mediano; quinto esterno com pequena projeção angulosa no meio da área discal e o bordo posterior anguloso; sexto esterno com o bordo um pouco côncavo.

Fêmea. Comprimento aproximado 6,22; comprimento da asa 4,76; largura da cabeça 2,32; comprimento do olho 1,61; distância interorbital superior 1,52 e a inferior 1,15. Cabeça amarelo-ferrugínea inclusive no clípeo, este com o ápice enegrecido; as mandíbulas e uma grande mácula frontal pre- tas, a mancha frontal mais larga dorsalmente incluindo os ocelos e ventralmente expandida até a sutura epistomal, contornando uma nódoa amarelo-ferrugínea entre as carenas interalveolares, a nódoa quase reta dorsalmente e com recorte em "V" invertido ventralmente; genas em grande parte amarelo-ferrugíneas com uma pequena área enegrecida ventral. Mesossoma como no macho; pernas com os artículos basais enegrecidos, fêmures e tíbias ferrugíneos e sem área amarela ao longo do comprimento, basitarsos medianos castanhos e os tarsos posteriores inteiramente enegrecidos. Tergos basais como no macho, o terceiro e o quarto com faixas amarelas laterais, um pouco mais estreitas nos flancos e separadas no meio por pequena área enegrecida; no quinto tergo a faixa amarela completa, com um pequeno recorte mediano anterior e outro posterior, nos flancos a faixa muito estreita; o tergo distal inteiramente preto.

Holótipo macho. Brasil, Mato Grosso do Sul. "Brasil, Mato Grosso do Sul/17 km NE de Porto/Murtinho Fazenda Anahi $21^{\circ} 38^{\prime}$ 'S 57 44'W, 100m/23.ii.2004, Melo \& Aguiar"; "DZUP/041233" (DZUP). Parátipos: com os mesmos dados do holótipo, um macho; da mesma localidade, $34 \mathrm{~km} \mathrm{SE} \mathrm{de}$ Porto Murtinho, $21^{\circ} 46^{\prime}$ S $57^{\circ} 34^{\prime}$ W, 100m, 24.ii.2004, Melo \& Aguiar, uma fêmea (DZUP).

Comentários. Nas espécies de Larocanthidium anteriormente descritas, no sexto tergo do macho a projeção mediana da lâmina subapical elevada é bissinuada ou retangular com os cantos arredondados. Para inserir a espécie descrita acima, na chave de Urban (1997), seria necessária uma modificação no ítem 2, referente a esse caráter e, a seguir $L$. chacoense sp. nov sairia com L. spinosum Urban, 1997, por ter espinho coxal nas pernas anteriores. Larocanthidium spinosum tem a lâmina do sexto tergo fracamente bissinuosa e o tergo distal bissinuoso com o recorte mediano côncavo e os lobos laterais rasos, largos e arredondados. A fêmea, sai com L. nigritulum Urban, 1997, pelo clípeo amareloferrugíneo e pela área supraclipeal preta. Larocanthidium nigritulum tem nódoa alongada amarelo-ferrugínea ventralmente ao ocelo mediano, faixa distal amarela no escutelo, axilas amarelas com pequena área basal enegrecida e as faixas laterais do tergo basal separadas por uma distância maior que o comprimento do escapo.

Etimologia. Nome relativo à sub-região biogeográfica do centro-oeste brasileiro.

\section{Epanthidium araranguense Urban, 2006}

(Figs. 4 e 5)

Epanthidium araranguense Urban, 2006: 43.

A espécie foi descrita com base em um exemplar fêmea coletado em Araranguá, Santa Catarina. Um macho coletado no Rio Grande do Sul é descrito a seguir.

Diagnose. Mandíbulas e máculas cefálicas amarelas, faixa pós-ocelar, axilas e metade distal do escutelo ferrugíneos; tergo basal com faixa amarela irregular, interrompida no meio e orlada com ferrugíneo; segundo tergo com faixa subapical 

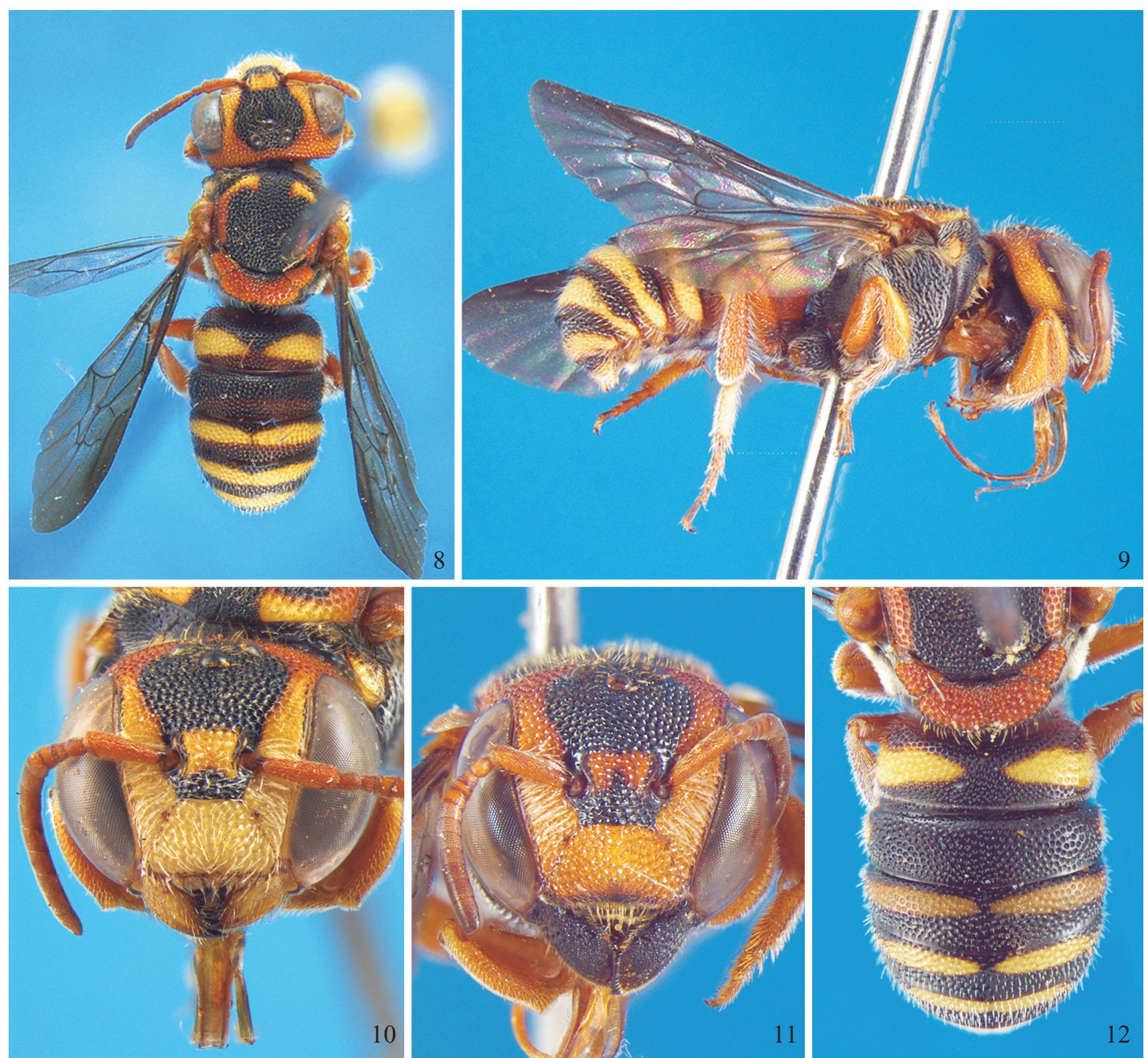

Figuras 8-12. Larocanthidium chacoense sp. nov. Holótipo macho (8-10): 8, vista dorsal; 9, perfil; 10, cabeça. (11-12). Parátipo fêmea: 11, cabeça; 12, área distal do mesossoma e tergos.

ferrugíneo-acastanhada estreita unida anteriormente a uma faixa dorsal ferrugíneo-pálida, estreita no meio e alargada nos lados; os dois tergos seguintes com um par de nódoas amarelas dorsais grandes e orladas com ferrugíneo posteriormente, quinto e sexto tergos com faixa dorsal amarela bissinuada.

Macho. Comprimento aproximado 9,54; comprimento da asa 8,51 ; largura da cabeça 3,43; distância interorbital superior 2,05 e a inferior 1,64. Tegumento predominante preto. Cabeça com as mandíbulas e o clípeo amarelos e orlados com preto, o clípeo com áreas látero-basais pretas e dois pontos enegrecidos perto do ramo transversal da sutura epistomal; áreas paroculares inferiores amarelas quase até o nível dos alvéolos, a mancha amarela estreitando muito em direção aos olhos e terminando finamente na altura da área ocelar; duas pequenas nódoas no meio da face, uma amarelo-ferrugínea junto à sutura epistomal e outra amarela próxima do ocelo mediano; faixa pós-ocelar ferrugínea até o terço dorsal das genas e aí mais larga. Antenas com o escapo, pedicelo e os dois flagelômeros basais ferrugíneos, o escapo amarelo ventralmente, demais flagelômeros pretos. Mesoscuto com duas nódoas pequenas látero-basais ferrugíneas, as nódoas com área discal amarela, muito estreitas nos lados, mais largas para o meio e com um prolongamento fino e curto em direção ao disco do mesoscuto; axilas e metade distal do escutelo ferrugíneos; tégulas ferrugíneas com orla translúcida âmbar; asas tingidas de enegrecido. Pernas com os artículos basais pretos, incluindo grande parte dos fêmures; nas anteriores os 
fêmures pretos menos no ápice e ferrugíneo-amarelados na face anterior; os fêmures medianos e posteriores ferrugíneoamarelados só no ápice; tíbias e tarsos ferrugíneo-amarelados, menos os basitarsos posteriores com a face externa amarela e os tarsômeros medianos acastanhados. Tergos pretos com as seguintes áreas claras: o basal com faixas laterais amarelas estreitas, quase até o meio, com a margem anterior arqueada para trás nos flancos e a posterior bissinuada, as faixas contornadas com ferrugíneo e separadas por pequena área ferrugínea; o segundo com uma faixa subapical ferrugíneo-acastanhada, mais próxima do bordo nos lados, a faixa unida anteriormente a uma faixa dorsal ferrugíneo-pálida, estreita no meio, alargada nos lados e com as pontas laterais angulosas e, com nódoas laterais amarelas estreitas; terceiro e quarto tergos com nódoas amarelas grandes, um pouco ovaladas e separadas medialmente por uma pequena distância, orladas posteriormente por uma estria ferrugínea acastanhada; quinto e sexto tergos com faixa amarela dorsal, bissinuada anteriormente e com a margem posterior reta; tergo distal preto na base, ferrugíneo na metade distal e o bordo preto; esternos castanhos.

Pilosidade esbranquiçada; clípeo abaulado, sem carena mediana, com pontuação uniforme e sem áreas desprovidas de pontos; tégulas polidas e denso-pontuadas. Discrímen mesepisternal carenado e elevado em arco na metade basal. Sétimo tergo com o espinho mediano mais longo que os lobos laterais, separado dos lobos por recortes côncavos e largos; lados do segundo esterno com projeções subapicais angulosas.

Material examinado. Rio Grande do Sul, Torres, Guaritas, 22.XI.2007, K. Ramos \& L. R. Faria Jr., 1 macho (DZUP).

Comentários. Na chave de Urban (1995) E. araranguense sai com E. confusum (Smith, 1879) conhecido de Córdoba e Mendoza, Argentina, que difere pelos seguintes caracteres: duas máculas ferrugíneas largas, em "J” invertido até o ápice do mesoscuto; escutelo inteiramente ferrugíneo; todos os tergos largamente ferrugíneo-amarelados nos flancos, o tergo basal ferrugíneo-amarelado com ou sem faixa discal amarela no disco, o segundo tergo preto só na base e, no restante ferrugíneo com faixa discal larga ferrugíneo-amarelada e, as pernas ferrugíneo-amareladas menos os dois artículos basais pretos nas anteriores; nas pernas medianas e posteriores, além das coxas e trocanteres, com área preta em grande parte da face ventral dos fêmures.

\section{Epanthidium bolivianum Urban, 1995}

(Figs. 6-7)

Epanthidium bolivianum Urban, 1992 [1995]: 12.

Espécie conhecida anteriormente pelo holótipo fêmea, de Luis Calvo, Bolívia. Um macho coletado, na Estrada para a Fazenda Pirizal, Porto Murtinho, Mato Grosso do Sul, é descrito a seguir.
Diagnose. Cabeça com as mandíbulas, o clípeo e as paroculares inferiores amarelo-pálidos; mesepisternos e escutelo ferrugíneos; mesoscuto com duas máculas ferrugíneas em " $U$ ” invertido, as máculas com uma pequena área basal amarela.

Macho. Comprimento aproximado 6,91; comprimento da asa 5,30; largura da cabeça 2,75; distância interorbital superior 1,52 e a inferior 1,21. Cabeça predominantemente ferrugínea, menos as mandíbulas, o clípeo e as paroculares inferiores amarelo-pálidos, as mandíbulas com os dentes e os contornos superior e inferior pretos; o clípeo com a margem e pequenas áreas enegrecidas orladas com ferrugíneo nos cantos basais e, uma grande mácula preta em forma de arco irregular, dos cantos da área supraclipeal até a área ocelar, mais larga dorsalmente aos alvéolos antenais, quase reta e com pequeno chanfro mediano atrás dos ocelos, contornando medialmente uma área ferrugínea longa e larga, da área supraclipeal até o ocelo mediano; as máculas paroculares passando a ferrugíneas e muito estreitas acima dos alvéolos antenais, alargando dorsalmente. Antenas ferrugíneas do escapo ao segundo flagelômero, no restante pretas. Dorso do mesossoma preto menos os lobos pronotais, com área ferrugínea na base da carena laminada; o mesoscuto com duas grandes máculas ferrugíneas em " $U$ ” invertido, as máculas com pequena área amarela na base e em parte do ramo discal; escutelo, tégulas e grande parte dos mesepisternos ferrugíneos; metanoto castanho. Asas tingidas de enegrecido com área transparente subapical. Pernas predominantemente ferrugíneas menos, as anteriores com a coxa preta e nódoa amarela na base da tíbia; as medianas com coxa e trocanter pretos, mácula preta basal na face ventral do fêmur e nódoa amarela basal na tíbia; e as posteriores com a coxa preta com nódoa ventral amarela, trocanter preto, fêmur com nódoa preta nos dois terços basais e pequena mancha amarela subapical. Tarsômeros acastanhados menos a face externa amarelo-pálida nos basitarsos posteriores. Tergo basal ferrugíneo; os demais enegrecidos dorsalmente e ferrugíneos nos flancos, menos o segundo e o terceiro tergos com faixa distal ferrugíneo-acastanhada. Primeiro ao sexto tergo com quatro nódoas amarelas discais, as nódoas dorsais estreitas nos dois tergos basais, alargando e mais arredondadas nos dois seguintes, no quinto quase quadradas e muito reduzidas no sexto; as nódoas laterais ovaladas nos três tergos basais, estreitas nos dois seguintes e no sexto muito reduzidas ou ausentes. Tergo distal ferrugíneo-enegrecido na metade basal e amarelo-pálido distalmente.

Pilosidade branca, alongada e mais conspícua na cabeça, mesepisternos e esternos; tégulas denso-pontuadas e brilhantes; clípeo e área supraclipeal com carena mediana larga, baixa e irregular; axilas com o bordo posterior fracamente côncavo, mesepisternos sem carena médio-ventral; sexto tergo com carena longitudinal larga e baixa; sétimo tergo com carena mediana fina e laminada, até o ápice do espinho mediano, os lobos laterais curtos e largos, arredondados no bordo externo e fracamente angulosos na margem voltada para o meio, separados do espinho mediano por concavidades 
tão largas como os lobos; o bordo do sexto esterno fracamente convexo e com os cantos arredondados.

Material examinado. Mato Grosso do Sul, Porto Murtinho. Fazenda Anahi, 23.II.2004, Melo \& Aguiar, 1 macho e 2 fêmeas; Estrada para a Fazenda Pirizal, 25.I.2008, A. Martins \& A. J. C. Aguiar, 1 macho e 1 fêmea; Estrada Cachoeira do Rio Apa, 21.I.2008, A. Martins \& A. J. C. Aguiar, 1 fêmea (DZUP).

Comentários. Na chave de Urban (1995) o macho de $E$. bolivianum sai com E. erythrocephalum (Schrottky, 1902), pelo aspecto das áreas axilares angulosas com o bordo posterior ligeiramente côncavo. O macho de E. erythrocephalum tem porte maior, cerca de $11 \mathrm{~mm}$ de comprimento, a margem do sexto esterno côncava, limitada por projeções laterais angulosas e o sétimo tergo inteiramente ferrugíneo-acastanhado.

Variações. As carenas clipeal e supraclipeal pesentes nas fêmeas e no macho descrito; porém o macho coletado na Fazenda Anahi tem somente uma carena mediana muito curta, subapical no clípeo, não tem carena supraclipeal. Uma das fêmeas coletadas na Estrada para a Fazenda Anahi, com uma faixa preta entre os alvéolos antenais e, o macho da mesma coleta, com nódoa mediana preta alongada entre os alvéolos. Uma das fêmeas coletadas na Fazenda Anahi e as coletadas na Estrada Cachoeira do Rio Apa e na Estrada para a Fazenda Pirizal com as máculas mesoscutais ferrugíneas ovóides, mais largas anteriormente e com área discal preta. Somente uma fêmea com as máculas mesoscutais ferrugíneas como as no macho.

O holótipo de E. bolivianum, é um pouco menor que as fêmeas examinadas, o tegumento predominante da cabeça amarelo-acastanhado e o mesoscuto tem uma larga área mediana preta, mais larga nas extremidades e duas grandes áreas laterais amarelo-acastanhadas, mais pálidas no contorno.

\section{Ketianthidium zanolae Urban, 2000}

Ketianthidium zanolae Urban, 1999 [2000]: 161.

O gênero e a espécie foram propostos por Urban (2000) para um macho coletado na Argentina, Entre Rios, Santa Elena, em 1888 (DZUP). Pela primeira vez é registrada a ocorrência no Brasil de um macho coletado em Mato Grosso do Sul, 32 km SE de Porto Murtinho, 130m, 23.II.2004, por Melo \& Aguiar (DZUP).

\section{AGRADECIMENTOS}

Ao Conselho Nacional de Desenvolvimento Científico e Tecnológico (CNPq) pela Bolsa de Produtividade, a Lisiane Dilli Wendt e Vitor Antonio Nardino (Projeto Taxon line Rede Paranaense de Coleções Biológicas) pelas fotos.

\section{REFERÊNCIAS}

Michener, C. D. 2000. The Bees of the World. Baltimore and London, The John Hopkins University Press, 913 p.

Silveira, F. A.; G. A. R. Melo \& E. A. B. Almeida. 2002. Abelhas brasileiras Sistemática e Identificação. Belo Horizonte, Composição \& Arte, $253 \mathrm{p}$.

Urban, D. 1992 [1995]. Espécies novas de Epanthidium Moure, 1947 (Hymenoptera, Megachilidae, Anthidiinae). Acta Biológica Paranaense 21: $1-22$.

Urban, D. 1997. Larocanthidium, gen. n. de Anthidiinae do Brasil (Hymenoptera, Megachilidae). Revista Brasileira de Zoologia 14: 299-317.

Urban, D. 1999 [2000]. Gênero novo e espécies novas de Anthidiini e nota taxonômica (Hymenoptera, Megachilidae). Acta Biológica Paranaense 28: $159-167$.

Urban, D. 2006. Espécies novas de Epanthidium Moure e de Austrostelis Michener \& Griswold (Hymenoptera, Apidae, Megachilinae). Revista Brasileira de Entomologia 50: 43-48. 